\title{
Iki farklı tip tahribatsız portatif klorofil metre kullanarak Artvin'de yayılış gösteren sapsız meşede (Quercus, Fagaceae) klorofil tahmini
}

\author{
Estimation of chlorophyll in sessile oak (Quercus, Fagaceae) naturally distributed in Artvin province using two \\ different types of non-destructive portable chlorophyll meter
}

\author{
Mehmet DEMiRALAY iD, Murat Sabri SADIKLAR (iD, Fahrettin Tilki iD \\ Artvin Çoruh Üniversitesi Orman Fakültesi Orman Mühendisliği Bölümü, Artvin Türkiye
}

\section{Eser Bilgisi/Article Info}

Araştırma makalesi / Research article

DOI: $10.17474 /$ artvinofd. 478915

Sorumlu yazar/Corresponding author

Murat Sabri SADIKLAR

e-mail: sadiklar@artvin.edu.tr

Geliş tarihi / Received

06.11.2018

Düzeltme tarihi / Received in revised form

28.01.2019

Elektronik erişim / Online available

31.01.2019

Anahtar kelimeler:

Aseton

CCM-300

Klorofil floresans

Sapsız meşe

SPAD-502Plus

Keywords:

Acetone

CCM-300

Chlorophyll fluorescence

Sessile oak

SPAD-502Plus

\begin{abstract}
Özet
Bu çalışmada, SPAD-502Plus ve CCM-300 adlı optik klorofil içerik ölçer cihazlarından elde edilen klorofil içerik değerleri ile \%80 aseton ile klorofil ekstraksiyon metodundan elde edilen klorofil içerik değerleri arasındaki ilişsinin saptanması amaçlanmıştır. Bu çalışma, sapsız meşenin, Quercus petraea (Mattuschka) Liebl. subsp. iberica (Steven ex Bieb.) Krassiln. alt türü üzerinde gerçekleştirilmiştir. Rakımı 889 m olan önceden belirlenmiş bir alandan benzer özelliklere sahip 11 ağaç seçilmiş, sağlıklı toplam 44 yaprak üzerinde ölçümler gerçekleştirilmiştir. Yapraklara ait SPAD, CFR (klorofil floresans) değerleri ve $\% 80$ aseton ile klorofil ekstraksiyonu devamında yapılan spektrofotometrik okumalar sonucunda elde edilen bulgular ayrı ayrı değerlendirilmiştir. Ölçümler sonucunda, her üç ölçüm tipi (SPAD, CFR ve $\% 80$ aseton metodu) sonuçlarının kuvvetli ilişki sergilediği tespit edilmiştir. Elde edilen SPAD ve CFR değerlerinin $\% 80$ aseton ile ekstraksiyon metodundan elde edilen verilere dönüştürülmesi amacıyla regresyon analizleri ile çeşitli eşitlikler oluşturulmuştur. Bu eşitlikler kullanılarak, SPAD ve CFR değerlerinin, kimyasal metodla tespit edilmiş klorofil içerik değerlerine dönüşümü mümkün olabilmektedir. Bu çalışmada, bu meşe türü için, birim alan başına yaprak toplam klorofil konsantrasyonu, SPAD $\left(R^{2}=0.9367\right)$ ve CFR $\left(R^{2}=0.8702\right)$ okumaları arasındaki ilişkinin, taze ağırlık başına yaprak toplam klorofil konsantrasyonuna göre (SPAD $\left(R^{2}=0.8264\right)$ ve CFR $\left.\left(R^{2}=0.7847\right)\right)$ daha yüksek olduğu tespit edilmiştir. Bu sonuçlara göre, bu optik cihazları kullanarak, tercihen birim alan başına $\left(\mathrm{mg} \mathrm{cm}^{-2}\right)$, yaprak toplam klorofil içeriği çok kısa sürede ve kolaylıkla yapraklara zarar vermeden belirlenebilir.
\end{abstract}

\begin{abstract}
In this study, it was aimed to determine the relationship between the chlorophyll content values obtained from SPAD-502Plus and CCM-300 optical chlorophyll content meters and the chlorophyll content values obtained from the chlorophyll extraction method using $80 \%$ acetone. This study was carried out on a subspecies of the sessile oak (Quercus petraea (Mattuschka) Liebl. subsp. iberica (Steven ex Bieb.) Krassiln.). 11 trees with similar characteristics were selected from a predefined area with an altitude of $889 \mathrm{~m}$ and measurements were made on a total of 44 healthy leaves. The leaf SPAD values, CFR (chlorophyll fluorescence) values and the results obtained from the spectrophotometric readings of the chlorophyll extraction with $80 \%$ acetone were evaluated separately. As a result of the measurements, it was determined that the results of all three measurement types (SPAD, CFR and $80 \%$ acetone method) showed a strong correlation. Various equations were formed by regression analyses in order to convert the obtained SPAD and CFR values to the values obtained from the $80 \%$ acetone method. Using these equations, it is possible to convert SPAD and CFR values into chlorophyll content values determined by chemical method. In this study, for this type of oak, the relationship between the leaf total chlorophyll concentration per unit area and SPAD $\left(R^{2}=0.9367\right)$ and CFR $\left(R^{2}=0.8702\right)$ readings was found higher than the leaf total chlorophyll concentration per fresh weight (SPAD $\left(R^{2}=0.8264\right)$ and CFR $\left.\left(R^{2}=0.7847\right)\right)$. According to these results, by using these optical devices, preferably per unit area $\left(\mathrm{mg} \mathrm{cm}^{-2}\right)$, the leaf total chlorophyll content can be determined in a very short time and easily without damaging the leaves.
\end{abstract}

\section{GiRiş}

Klorofil-a ve klorofil-b pigmentleri bitkisel fotosentezde rolü olan en önemli biyolojik moleküllerdendir. Biyosfere enerji sağlayan güneş enerjisinin, yapraklarda depolanmış kimyasal enerjiye dönüştürülmesi sürecinde rol alırlar. Bu yüzden bilimsel açıdan yaprak klorofil içeriği tek başına bile kayda değer incelenmesi gereken bir parametredir (Richardson et al. 2002). Ayrıca, yaprak 
klorofil içeriğinin kendi içinde ve türler arasında nasıl bir değişim gösterdiği ve bunun sebepleri anlaşılmalıdır.

Aynı zamanda özellikle tarım ve ormancılık alanında da yaprak pigmentasyonu çok büyük bir önem arzeder. Bu durumun sebeplerinden birincisi, bir yaprak tarafından absorbe edilen güneş ışığı miktarı, başlıca yapraktaki fotosentetik pigment konsantrasyonu ile ilgilidir. Dolayısıyla klorofilin düşük konsantrasyonda olması direkt olarak fotosentetik potansiyeli ve primer üretimi sınırlandırmaktadır (Curran et al. 1990; Filella et al. 1995). İkincisi, yaprak azotunun klorofil ile ilişki içinde olmasından dolayı klorofil içeriğinin hesaplanması, bitkinin besin durumunun ölçülmesi için dolaylı bir yol olabilmektedir (Filella et al. 1995; Moran et al. 2000). Üçüncüsü, pigmentasyon direkt olarak bitki stres fizyolojisi ile ilgili olabilmektedir. Genellikle, stres altında ve yaşlanma süresince karetenoid konsantrasyonu artar ve klorofil konsantrasyonu düşer (Peñuelas and Filella 1998). Dördüncüsü, pigment konsantrasyon oranları ışık gibi çevresel faktörlerden etkilenir. Örneğin, ışık yaprakları daha yüksek bir klorofil-a : klorofil-b değerine sahiptir (Larcher 1995). Böylelikle bu oranların hesaplanması, bitkiler ve çevreleri arasındaki ilişkiler hakkında önemli bilgiler sağlayacaktır (Richardson et al. 2002).

Yaprak klorofil miktarı genelde ya konsantrasyon ( $\mu \mathrm{g} \mathrm{Chl}$ $\mathrm{g}^{-1}$ doku) ya da içerik ( $\mathrm{mg} \mathrm{Chl} \mathrm{cm}^{-2}$ doku) olarak ifade edilir. Bazen de klorofil konsantrasyonu ve içeriği, kütle veya alan başına mol olarak ifade edilir. Çünkü, foton akışı ve karbon asimilasyon hızları benzer birimlerle ifade edilmektedir, bu da fizyolojik sürecin daha iyi anlaşılmasına imkan vermektedir (Richardson et al. 2002). Hangi şekilde ifade edileceği, araştırmacının amacına bağlı olarak değişmektedir.

Geleneksel olarak, kimyasal metodlar klorofil ekstraksiyonunu, devamında da bunların absorbansının spektrofotometrik tespitini gerektirmektedir. Bulunan absorbans değerleri ayrıca yayınlanmış eşitlikler (Arnon 1949) ve modifikasyonlarla konsantrasyonlara dönüştürülmektedir. Ekstraksiyon süreci tek başına bile ciddi zaman alan bir olaydır. Her bir yaprak parçalanmakta ve klorofiller ekstrakte edilmeye çalışılmaktadır. Son zamanlarda ise yaprakların parçalanmasını gerektirmeyen, hatta yaprak dalından koparılmadan klorofil içeriğinin hesaplanabileceği cihazlar geliştirilmiştir. Bu cihazların temel çalışma mantığı, yaprağın absorbladığı ve/veya yansıttığı ışı̆ın ölçülmesine dayanmaktadır. Optik metodların genel olarak bir klorofil indeksi ortaya koydukları, direkt olarak alan başına klorofil içeriği veya kütle başına klorofil konsantrasyonunu vermedikleri bildirilmiştir (Markwell et al. 1995; Gamon and Surfus 1999). Bu yeni optik metodlar, yaprakların parçalanmasını, koparımasını gerektirmez böylelikle arazide çok hızlı şekilde ölçüm yapılmasına olanak sağlarlar.

El tipi klorofil absorbans ölçerleri ticari olarak piyasada mevcuttur. Bunların en çok tercih edilenlerinden biri de SPAD-502Plus'tır. Bu cihaz, ışığın iki farklı dalga boyunda 660 nm (kırmızı) ve 940 nm (yakın kızıl ötesi)'de, absorbans ölçmektedir. Kırmızı ışık klorofil tarafından kuvvetli şekilde absorblanır; yakın kızıl ötesi ışık ise yaprak yapısındaki farklııkların ayarlanması için kullanılan referans dalga boyudur. Bu klorofil içerik ölçer cihazların dayandığı temel teorik mantık detayları ile Markwell et al. (1995) tarafından ortaya konmuştur (Richardson et al 2002). \%80 konsantrasyona sahip aseton kullanılarak klorofil ekstraksiyonu sonucu absorbans grafiği çizilirse, $400-500 \mathrm{~nm}$ ve $600-700 \mathrm{~nm}$ aralıklarında pikler oluştuğu ancak yakın infrared bölgede absorbansın gerçekleşmediği görülmektedir. SPAD-502Plus cihazı da bu avantajdan yararlanarak ölçüm yapmaktadır. Yani kırmızı ve yakın kızıl ötesi bölgelerdeki absorbansları ölçmektedir. Bundan yararlanarak da, yapraktaki klorofil içeriğini sayısal bir SPAD değeri olarak ifade etmektedir (Richardson et al. 2002).

CCM-300 cihazı da son yıllarda çokça kullanılan bir optik klorofil metredir. Bu cihaz absorblama tekniği yerine klorofil floresans tekniği ile çalışmaktadır. CFR veya Klorofil Floresans Oranı 735 nm/700 nm de floresans emisyon yoğunluğunu ölçmektedir. Ayrıca direkt olarak oransal klorofil içeriğini $\mathrm{mg} \mathrm{m}^{-2}$ olarak da verebilmektedir. Bu cihaz, Gitelson et al. (1999) tarafından yapılan bilimsel çalışma sonuçlarına göre dizayn edilmiştir. Hem laboratuvar hem arazi testleri, 
CCM-300 klorofil içerik ölçerin $41 \mathrm{mg} \mathrm{m}^{-2}-675 \mathrm{mg} \mathrm{m}^{-2}$ klorofil konsantrasyonu aralığında oldukça yüksek doğrulukta ölçümler gerçekleştirdiğini ortaya koymuştur.

Portatif bir klorofil metre ile klorofil içeriği ölçümü yapılması, geleneksel metodlara göre bazı avantajlar sağlamaktadır. Ölçümlerin aynı çevresel şartlar altında kısa sürede bitirilebilmesi, düşük maliyetli olması, çok sayıda örneğin geniş alanlarda incelenebilmesi, her bir örnek üzerinde çok sayıda ölçüm yapılabilmesi ve ortalama alma şansının bulunması, örneklerin canlılığını sürdürmesi ve örnekler üzerinde daha sonraki dönemlerde de ölçüm yapma imkanının olması vb. bu cihazlarla ölçüm yapmanın getirdiği avantajlardan bazılarıdır.

Klorofil ekstraksiyonu için aseton, DMSO (Dimetil Sülfoksit), metanol vb. çeşitli kimyasallar sıklıkla kullanılmaktadır. Özellikle aseton kullanımı geleneksel bir yöntem olarak dünya çapında uzun yıllardır tercih edilmektedir. Dolayısıyla da aseton ile klorofil ekstraksiyonu ile gerçekleştirilmiş çok sayıda bilimsel çalışma literatürde yer almaktadır. Asetonun farklı konsantrasyonlarına dayalı modifiye edilmiş çok sayıda yöntem olsa da sıklıkla $\% 80$ aseton ile klorofil ekstraksiyonu metodu tercih edilmektedir. Böylelikle çok sayıda çalışmanın sonuçları kıyaslanabilmektedir.

$\mathrm{Bu}$ çalışmanın temel amacı, uzun yıllardır tercih edilmesinden dolayı gelenekselleşmiş hale gelen $\% 80$ aseton kullanarak klorofil konsantrasyonu/içeriği belirleme yöntemi ile önde gelen iki optik klorofil içerik ölçer (SPAD-502Plus ve CCM-300) değerleri arasındaki ilişkinin derecesini, sapsız meşe örneği üzerinde göstermektir. Bu üç yönteme ilişkin yapılan regresyon analizleri ile en yüksek $R^{2}$ değerine sahip cihazın belirlenmesi amaçlanmıştır. Bu cihazların kullanımından elde edilecek tahmini değerlerin kimyasal yöntem ile klorofil içerik ölçümü değerlerine dönüştürülebilmesi için uygun eşitlikler oluşturulmaya çalışılmıştır. Böylelikle, bu tip taşınabilir optik klorofil metre cihazlarının orman ağacı türlerinde klorofil miktarı belirlenmesinde kullanımının uygun olup olmayacağı konusundaki bilimsel tartışmalara katkı sağlanması hedeflenmiştir.

\section{MATERYAL ve YÖNTEM}

\section{Deneme Alanının Genel Tanıtımı}

Deneme alanı olarak seçilen bölge, Artvin ili sınırları içerisinde, şehir merkezine yaklaşık $10 \mathrm{~km}$ uzaklıkta bulunmaktadır $\left(41^{\circ} 12^{\prime} 36.12^{\prime \prime} \mathrm{K}\right.$ ve $\left.41^{\circ} 50^{\prime} 58.62^{\prime \prime} \mathrm{D}\right)$. Deneme alanının, denizden ortalama yüksekliği 889 metredir. Kuzey bakıya sahip alanın ortalama eğim derecesi \%10'dur. 1/25000 Ölçekli Ulusal Toprak Veri Tabanına göre deneme alanının bulunduğu bölgenin Büyük Toprak Grubu (BTG), kahverengi orman toprakları (M) sınıfındadır. Alanın hakim bitki örtüsü meşedir. Meşcere tipi Mzb3'tür. Alanda bulunan meşe türü Sapsız Meşe (Quercus petraea (Mattuschka) Liebl. subsp. iberica (Steven ex Bieb.) Krassiln.)'dir. Arazi ve laboratuvar çalışmaları vejetasyon dönemi sonuna doğru, 2016 yılı ekim ayı içerisinde yapılmıştır.

Deneme alanı yazları sıcak, kışları soğuk bir iklime sahiptir. Bununla beraber, en yüksek yağışı kış mevsimi ve sonbaharda almaktadır. Alana en yakın Artvin Meteoroloji İstasyonu'nun (625 m) 1954-2013 yılları arasına ait uzun dönem meteorolojik ölçüm verileri, 889 $\mathrm{m}$ de bulunan deneme alanına göre enterpole edidiğinde, ortalama sıcaklığın en yüksek olduğu ayın $19.4{ }^{\circ} \mathrm{C}$ ile Ağustos, en düşük olduğu ayın ise $1.3{ }^{\circ} \mathrm{C}$ ile Ocak olduğu görülmektedir. Ayrıca en yüksek ortalama aylık yağışın 103.1 mm ile Aralık ayında, en düşük ortalama aylık yağışın ise $41.3 \mathrm{~mm}$ ile Ağustos ayında gerçekleştiği görülmektedir. Yıllık ortalama yağış ise $841.6 \mathrm{~mm}$ olarak gerçekleşmiştir.

\section{Yapılan Ölçümler}

\section{Toplam klorofil içeriği tahmini (SPAD-502Plus ve CCM- 300)}

Belirlenmiş yapraklar üzerinde, klorofil içeriği ölçümleri yapılmıştır. Klorofil içeriği ölçümü için portatif klorofil metreler (SPAD 502Plus, Konica Minolta, Osaka, Japan) ve CCM-300 (Opti-Sciences, Hudson, USA) tercih edilmiştir. Böylelikle yaprakların dallarından koparılmasına gerek kalmaksızın çok kısa sürede, aynı şartlar altında ölçümler gerçekleştirilebilmiştir.

SPAD ve CFR (F735/F700) ölçümleri, farklı renk tonlarına sahip, sağ|ıklı, parçalanmamış, tam güneş gören aynı 44 
yaprak üzerinde gerçekleştirilmiştir. Bu yapraklar, aralarında belirli mesafe olan 11 ağacın, $2 \mathrm{~m}$ yükseklikteki tam güneş gören dış dallarından dörder tane olacak şekilde seçilmiştir. Sağlıklı sonuçlar alabilmek için yaprakların üzerinde toz olma ihtimaline karşı, dikkatli bir şekilde yaprak yüzeyleri temizlenmiştir. Cihazların direkt güneş ışığına maruz kalmasının sonuçlar üzerinde istenmeyen etkiler yaptığı bilgisinden yola çıkılarak, güneşe karşı duruş yönü ve tutuş açısına azami dikkat edilmiştir. Tüm bu hazırlıklardan sonra her bir yaprakta, damarlara denk gelmeyen ve yaprağın farklı bölgelerinden olmak kaydıyla 10’ar ölçüm yapılmış, sonra bu 10 ölçümün ortalaması o yaprağa ait tahmini klorofil içerik (SPAD) ve CFR değeri olarak kaydedilmiştir (Gitelson et al. 1999; Richardson et al. 2002).

SPAD ve CFR ölçümü yapılan aynı yapraklar üzerinde $\% 80$ aseton ile ekstraksiyon yöntemi ile biyokimyasal toplam klorofil içerik ölçümü gerçekleştirilmiştir. Bu amaçla, seçilen yapraklar, SPAD ve CFR ölçümleri tamamlandıktan sonra, sapları ile beraber dallarından ayrılmış ve hızlıca numaralandıııımış kilitli plastik poşetlere aktarımıştır. Poşetler kapatılmadan, içlerine hava üflenerek $\mathrm{CO}_{2}$ miktarı ve hava nemi arttırılmaya çalışılmış, böylelikle de transpirasyonal su kaybının azaltılması amaçlanmıştır. Ağzı kapatılan kilitli poşetler, daha önceden soğutucuda dondurulmuş özel buz kasetlerinin bulunduğu portatif soğuk saklama ve taşıma çantasına yerleştirilmiştir. Yapraklar, mümkün olan en kısa sürede diğer ileri çalışmalar için laboratuvara ulaştırılmış ve aseton yöntemi ile analiz edilinceye kadar $-20{ }^{\circ} \mathrm{C}^{\prime}$ de saklanmıştır.

\section{\%80 aseton yöntemi ile klorofil içeriği tayini}

$\% 80$ konsantrasyona sahip soğuk aseton $\left(-20^{\circ} \mathrm{C}\right)$, klorofil ekstraksiyonu için kullanılmıştır. Her bir yapraktan, yaklaşık toplam ağırlığı $0.1 \mathrm{~g}$ olacak şekilde, alanı belli, çeşitli sayıda yaprak diskleri alınmıştır. Sonraki hesaplamalarda kullanılmak üzere, her bir yaprak örneği için toplam yaprak disk sayıları kaydedilmiş ve toplam taze disk ağırlıkları hassas analitik terazide (XB220A,
Precisa) ölçülmüştür. Her bir örneğe ait yaprak diskleri eppendorf tüpler içine konulmuş, önce 5 dakika kuru, sonra $1.6 \mathrm{ml}$ aseton içinde 20 dakika Tissuelyser LT (Qiagen) homojenizatör cihazı ile homojenize edilmiştir. Devamında $10000 \mathrm{~g}$ de soğutmalı santrifüj cihazında +4 ${ }^{0} C^{\prime}$ de santrifüj işlemi yapılmış, alınan süpernatant 10 kat, aseton ile seyreltilmiştir. Her bir örnek için 4 ekstrakt hazırlanmış, ekstraktların absorbansları spektrofotometrede 645 ve 663 nm'de okunmuştur. Her bir yaprak örneği için bu dört ölçümün ortalaması alınmıştır. Toplam klorofil içeriği taze ağırlık başına mg g${ }^{1}$ ve alan başına $\mathrm{mg} \mathrm{cm}^{-2}$ olarak, Arnon (1949)'a göre hesaplanmıştır. Bu amaçla kullanılan formüller aşağıda gösterilmiştir:

Klorofil-a İçeriği $=\left(12.7 \times A_{663}\right)-\left(2.69 \times A_{645}\right)$

Klorofil-b iç̧eriği $=\left(22.9 \times A_{645}\right)-\left(4.68 \times A_{663}\right)$

Toplam Klorofil İçeriği=Klorofil-a+Klorofil-b

Kullanılan aseton miktarı, yaprak disk ağırlıkları ve alanları dikkate alınarak gerekli dönüşümler yapılmıştır.

\section{İstatistiksel analizler}

Bitki örnekleri üzerinde, SPAD, CFR değerleri ve $\% 80$ aseton ile ekstraksiyon yönteminden elde edilen verilerin ilişkilendirilmesi amacıyla regresyon analizi uygulanmıştır. İstatistiksel analizlerin yapılmasında, SPSS paket programı (SPSS 16.0) ve Microsoft Excel 2010 programından faydalanılmıştır.

\section{BULGULAR VE TARTIŞMA}

Alanda belirlenen 11 ağaç üzerinde bulunan 44 yaprak üzerinde gerçekleştirilen ölçümler sonucunda elde edilen bulgular şekil 1, 2, 3, 4 ve 5'de gösterilmiştir. Bu çalışmada elde edilen SPAD ve CFR (F735/F700) değerleri ile $\% 80$ aseton ile ekstraksiyon yönteminden elde edilen klorofil içerik değerleri istatiksel olarak regresyon analizine tabi tutulmuştur. Analiz sonucunda, çeşitli denklemler elde edilmiştir (Şekil 1-5). 

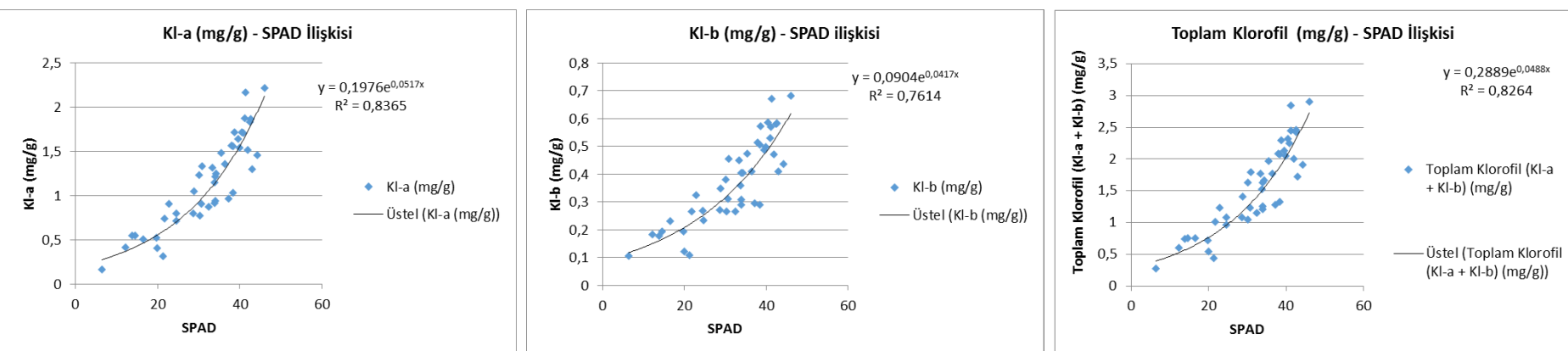

Şekil 1. SPAD ve $\% 80$ aseton yöntemi ile taze ağırlık başına $\left(\mathrm{mg} \mathrm{g}^{-1}\right)$ klorofil içerik değerlerinin regresyon grafikleri. $\mathrm{Kl}-\mathrm{a}\left(\mathrm{mg} \mathrm{g}^{-1}\right)-\mathrm{SPAD}$ ilişkisi: $y=0.1976 \mathrm{e}^{0.0517 x}\left(\mathrm{R}^{2}=0.8365\right) ; \mathrm{KI}-\mathrm{b}\left(\mathrm{mg} \mathrm{g}^{-1}\right)$ - SPAD ilişkisi: $\mathrm{y}=0.0904 \mathrm{e}^{0.0417 x}\left(\mathrm{R}^{2}=0.7614\right)$; Toplam klorofil (KI-a + Kl-b) (mg/g) - SPAD ilişkisi: $y=0.2889 e^{0.0488 x}\left(R^{2}=0.8264\right)$.
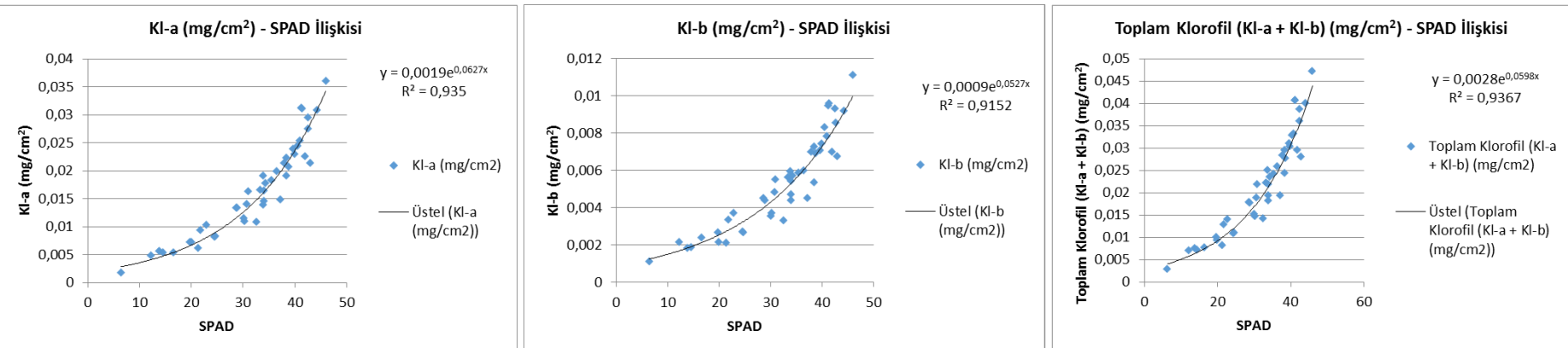

Şekil 2. SPAD ve $\% 80$ aseton metodu ile birim alan başına $\left(\mathrm{mg} \mathrm{cm}^{-2}\right)$ klorofil içerik değerlerinin regresyon grafikleri. $\mathrm{Kl}-\mathrm{a}\left(\mathrm{mg} \mathrm{cm}^{-2}\right)-\mathrm{SPAD}$ ilişkisi: $\mathrm{y}=0.0019 \mathrm{e}^{0.0627 x}\left(\mathrm{R}^{2}=0.935\right) ; \mathrm{Kl}-\mathrm{b}\left(\mathrm{mg} \mathrm{cm}^{-2}\right)$ - SPAD ilişkisi: $\mathrm{y}=0.0009 \mathrm{e}^{0.0527} \times\left(\mathrm{R}^{2}=0.9152\right) ;$ Toplam klorofil $(\mathrm{Kl}-\mathrm{a}+\mathrm{KI}-\mathrm{b})\left(\mathrm{mg} \mathrm{cm}^{-2}\right)-\mathrm{SPAD}$ ilişkisi: $y=0.0028 e^{0.0598 x}\left(R^{2}=0.9367\right)$.
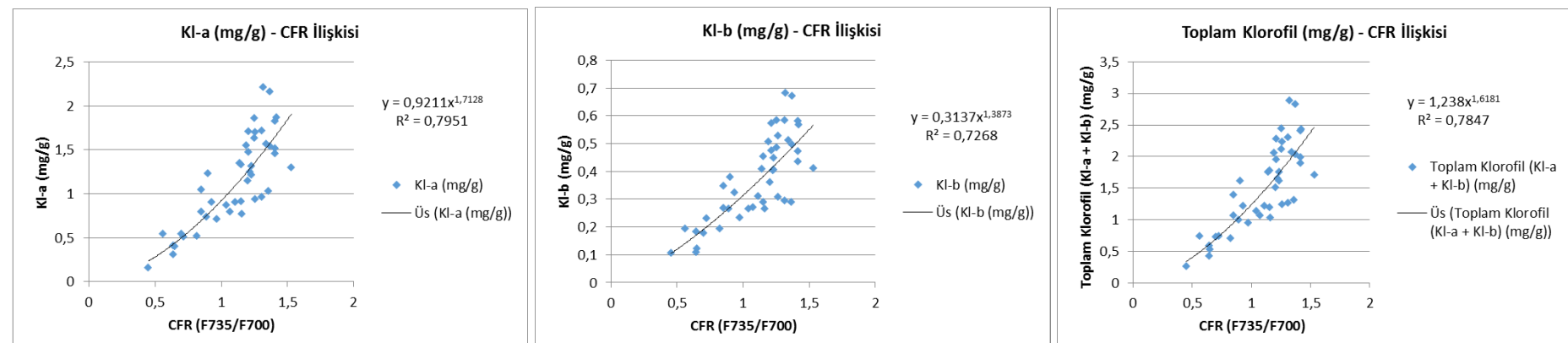

Şekil 3. CFR ve aseton metodu ile taze ağılık başına $\left(\mathrm{mg} \mathrm{g}^{-1}\right)$ klorofil içerik değerlerinin regresyon grafikleri. $\mathrm{Kl-a}\left(\mathrm{mg} \mathrm{g}^{-1}\right)$ - CFR ilişkisi: $y=0.9211 x^{1.7128}\left(R^{2}=0.7951\right) ; K I-b\left(m g ~ g^{-1}\right)-C F R$ ilişkisi: $y=0.3137 x^{1.3873}\left(R^{2}=0.7268\right) ;$ Toplam klorofil (KI-a + KI-b) (mg g g) - CFR ilişkisi: $y=1.238 x^{1.6181}$ $\left(R^{2}=0.7847\right)$.
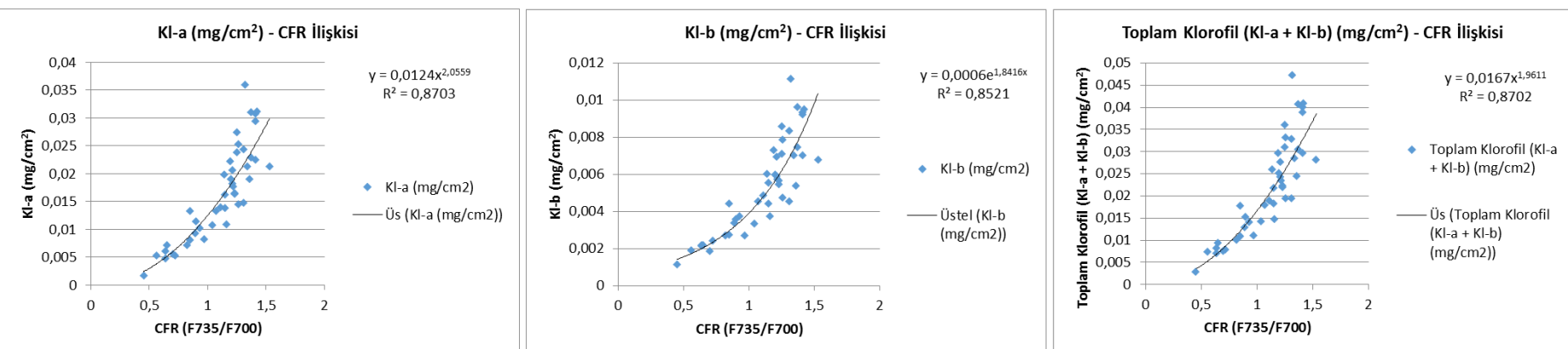

Şekil 4. CFR ve aseton metodu ile birim alan başına $\left(\mathrm{mg} \mathrm{cm}^{-2}\right)$ klorofil içerik değerlerinin regresyon grafikleri. $\mathrm{Kl}-\mathrm{a}\left(\mathrm{mg} \mathrm{cm}^{-2}\right)-\mathrm{CFR}$ ilişkisi:

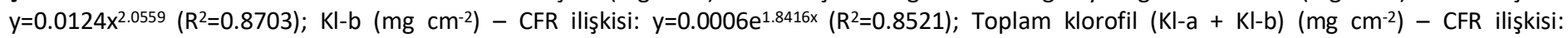
$y=0.0167 x^{1.9611}\left(R^{2}=0.8702\right)$. 
Bu eğrilerden elde edilen denklemler sayesinde SPAD ve CFR değerlerinin, $\% 80$ aseton kullanılan klorofil ekstraksiyon metodu ile tespit edilmiş klorofil içerik değerlerine dönüşümü mümkün olabilmektedir.

Regresyon analizleri sonucunda elde edilen $R^{2}$ değeri en yüksek denklemler aşağıda verilmiştir:

$\mathrm{Kl}-\mathrm{a}\left(\mathrm{mg} \mathrm{g}^{-1}\right)$ - SPAD ilişkisi:

$y=0.1976 e^{0.0517 x}\left(R^{2}=0.8365\right)$

$\mathrm{Kl}-\mathrm{a}\left(\mathrm{mg} \mathrm{g}^{-1}\right)-\mathrm{CFR}$ ilişkisi:

$y=0.9211 x^{1.7128}\left(R^{2}=0.7951\right)$

$\mathrm{KI}-\mathrm{b}\left(\mathrm{mg} \mathrm{g}^{-1}\right)$ - SPAD ilişkisi:

$y=0.0904 e^{0.0417 x}\left(R^{2}=0.7614\right)$

$\mathrm{KI}-\mathrm{b}\left(\mathrm{mg} \mathrm{g}^{-1}\right)$ - CFR ilişkisi:

$y=0.3137 x^{1.3873}\left(R^{2}=0.7268\right)$

Toplam klorofil (Kl-a + Kl-b) $\left(\mathrm{mg} \mathrm{g}^{-1}\right)$ - SPAD ilişkisi:

$y=0.2889 e^{0.0488 x}\left(R^{2}=0.8264\right)$

Toplam klorofil (KI-a + Kl-b) $\left(\mathrm{mg} \mathrm{g}^{-1}\right)$ - CFR ilişkisi:

$y=1.238 x^{1.6181}\left(R^{2}=0.7847\right)$

$\mathrm{KI}-\mathrm{a}\left(\mathrm{mg} \mathrm{cm}^{-2}\right)$ - SPAD ilişkisi:

$y=0.0019 e^{0.0627 x}\left(R^{2}=0.935\right)$

$\mathrm{KI}-\mathrm{a}\left(\mathrm{mg} \mathrm{cm} \mathrm{cm}^{-2}\right)$ - CFR ilişkisi:

$y=0.0124 x^{2.0559}\left(R^{2}=0.8703\right)$

$\mathrm{KI}-\mathrm{b}\left(\mathrm{mg} \mathrm{cm}^{-2}\right)$ - SPAD ilişkisi:

$y=0.0009 e^{0.0527 x}\left(R^{2}=0.9152\right)$

$\mathrm{KI}-\mathrm{b}\left(\mathrm{mg} \mathrm{cm}^{-2}\right)$ - CFR ilişkisi:

$y=0.0006 e^{1.8416 x}\left(R^{2}=0.8521\right)$

Toplam klorofil (KI-a $+\mathrm{KI}-\mathrm{b})\left(\mathrm{mg} \mathrm{cm}^{-2}\right)$ - SPAD ilişkisi:

$y=0.0028 e^{0.0598 x}\left(R^{2}=0.9367\right)$

Toplam klorofil (Kl-a $+\mathrm{KI}-\mathrm{b})\left(\mathrm{mg} \mathrm{cm} \mathrm{cm}^{-2}\right)-\mathrm{CFR}$ ilişkisi:

$y=0.0167 x^{1.9611}\left(R^{2}=0.8702\right)$

CFR - SPAD ilişkisi:

$y=0.0262 x+0.2672\left(R^{2}=0.9011\right)$
$\mathrm{R}^{2}$ değeri en yüksek denklemler incelendiğinde, birim alan başına $\left(\mathrm{mg} \mathrm{cm}^{-2}\right)$ yapılan tüm hesaplamaların (Şekil 2 ve Şekil 4), taze ağırlık başına $\left(\mathrm{mg} \mathrm{g}^{-1}\right)$ yapılan hesaplamalara (Şekil 1 ve Şekil 3) göre daha iyi sonuçlar verdiği görülmektedir.

Yapılan çalışmalar neticesinde $R^{2}$ değeri en yüksek denkleme, birim alan başına $\left(\mathrm{mg} \mathrm{cm}^{-2}\right.$ ) toplam klorofilin SPAD ile ilişkisini ortaya koyarken ulaşılmıştır. Toplam klorofil (Kl-a+KI-b) $\left(m g \quad \mathrm{~cm}^{-2}\right) \quad-$ SPAD ilişkisi: $\mathrm{y}=0.0028 \mathrm{e}^{0.0598 x}\left(\mathrm{R}^{2}=0.9367\right)$ denkleminden yola çıkılarak, sapsız meşede toplam klorofil içerik hesaplamasının birim alan başına $\left(\mathrm{mg} \mathrm{cm}^{-2}\right)$ olacak şekilde, SPAD-502Plus cihazı ile yüksek doğruluk oranı ile gerçekleştirilebileceği söylenebilir (Şekil 2).

Toplam klorofil $(\mathrm{Kl}-\mathrm{a}+\mathrm{KI}-\mathrm{b})\left(\mathrm{mg} \mathrm{cm} \mathrm{cm}^{-2}\right)$ - CFR ilişkisi: $y=0.0167 x^{1.9611} \quad\left(R^{2}=0.8702\right) \quad$ denkleminden de anlaşılabileceği üzere, CCM-300 cihazı da, sapsız meşede toplam klorofil içerik hesaplaması birim alan başına (mg $\mathrm{cm}^{-2}$ ) olacak şekilde, yüksek doğrulukla kullanılabilir (Şekil 4).

Benzer şekilde, birçok araştırmacı farklı bitki türlerinde benzer eşitlikler ortaya koymuşlardır. Bielinis et al. (2015), DMSO metodunu ve de SPAD-502Plus cihazını kullanarak Quercus petraea türü için $\mathrm{Y}=0.024 \mathrm{x}^{2}+2.1998 \mathrm{x}-32.7866, \quad\left(\mathrm{mg} \quad \mathrm{m}^{-2}\right), \quad\left(\mathrm{R}^{2}=0.84\right)$ eşitliğini öne sürmüştür. Percival et al. (2008), Quercus robur türü için $\mathrm{Y}=1.8159 \mathrm{X}^{0.8809}$, (mikrogram $\mathrm{g}^{-1}$ ) eşitliğini bulmuşlardır. Pinkard et al. (2006) ise Eucalyptus globulus türü için $Y=\exp (-6.49+1.46 \operatorname{lnx})\left(\right.$ mikrogram cm$\left.{ }^{-2}\right)$ denklemini üretmiştir.

Gitelson et al. (1999), kayın, karaağaç ve yabani üzüm asması yapraklarını kullanarak yaptıkları bir çalışmada, belirledikleri yaprak bölgelerinin reflektans, transmitans ve floresans spektralarını ölçmüşlerdir. Devamında ölçüm yaptıkları aynı yaprak noktalarındaki klorofil içeriğini nicel olarak hesaplamışlardır. Bu amaçla, Lichtenthaler (1987b)'in yeniden uyarlanmış eşitliklerini kullanarak aseton (\%100) ekstraksiyon çözeltisi içerisindeki yaprak korofil içeriğini spektrofotometrik olarak belirlemişlerdir. Çalışmaları sonucunda, F735/F700 klorofil floresans oranının, klorofil içeriği ile doğrusal orantılı olduğunu (determinasyon katsayısı, $R^{2}$, 
0.95 den fazla) ve bu oranın bitki yaprak klorofil içeriğinin belirlenmesinde kesin bir gösterge olarak kullanılabileceğini rapor etmişlerdir. Benzer şekilde, sapsız meşe üzerine yapılan bu çalışmada da, CCM-300 cihazı ile ölçülen F735/F700 klorofil floresans oranları ve birim alan başına yaprak klorofil içeriği arasında yüksek bir $R^{2}$ değerine ulaşılmıştır $\left(R^{2}=0.8702\right)$.

Görüldüğü üzere denklemler türden türe değişmektedir. Ayrıca SPAD okumalarının yaprak kalınlığından ve kloroplast hareketliliğinden etkilendiği de bilinmektedir (Sardoel et al. 2014). Dolayısıyla her bir tür için, ayrı ayrı, farklı dönemlerde SPAD ve CFR değerlerinin tespit edilmesi faydalı olacaktır.

Yaprak yüzeyinde, SPAD-502Plus ve CCM-300 ile yapılan okumaların regresyon analizi sonucunda elde edilen CFR - SPAD ilişkisi: $y=0.0262 x+0.2672$ $\left(R^{2}=0.9011\right)$ denklemi bize her iki optik klorofil metre cihazı verilerinin de birbiri ile yüksek ölçüde uyumlu olduğunu göstermektedir (Şekil 5).

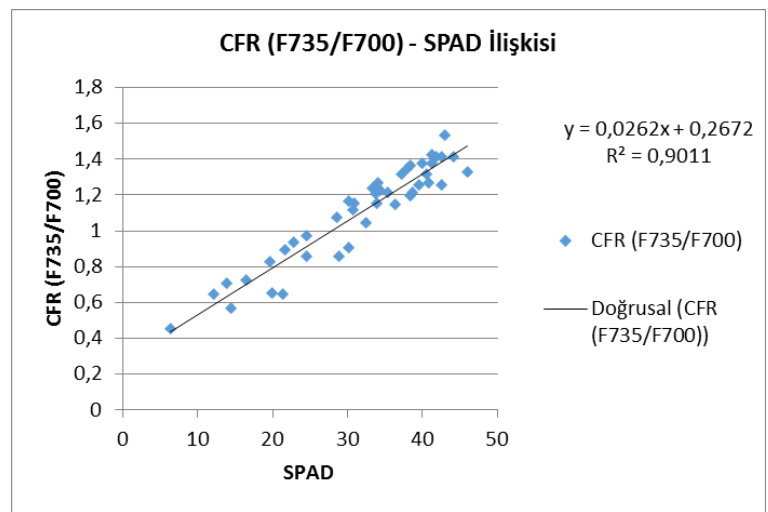

Şekil 5. SPAD ve CFR (F735/F700) değerlerinin regresyon grafiği. CFR - SPAD ilişkisi: $y=0.0262 x+0.2672\left(R^{2}=0.9011\right)$.

\section{SONUÇ}

Yaprak klorofil içeriğinin net fotosentez hızını etkileyebileceği ve klorofil içeriği ile SPAD değerleri arasında kuvvetli pozitif ilişki olduğu rapor edilmiştir (Monje and Bugbee 1992). Bununla birlikte, net fotosentez hızı ile klorofil içerik değerlerinin ilişkili olmadığı Fujimura et al. (2009) tarafından yapılan bir çalışma da mevcuttur. Yine de fotosentez hızının tespit edilmesinde dolaylı da olsa klorofil içerik değerlerinden yararlanılmaktadır.
Yaprak klorofil içeriğinin yaprak azot miktarı ile doğrudan ilişkili olduğu bilinmektedir. Azotun belli değerler arasında olması bitkinin sağıık ve beslenme durumu hakkında bilgi vermektedir. Dolayısıyla yapraklar üzerinde klorofil metre kullanarak yapılan hızlı, düşük maliyetli, zahmetsiz ve bitkiye zarar vermeyen klorofil içerik ölçümleri, bitki beslenme durumunu anlamada da pratik bir şekilde kullanılabilir. Klorofil içerik değerlerinin belli eşik değerler altında olması bitkinin stres altında olduğuna da işaret etmektedir. Dolayısıyla bitki klorofil içeriğinin düzenli aralıklarla ölçülmesi bitki sağlık durumu hakkında hayati derecede önemli bilgiler sağlar.

Bu çalışma sonucunda, $\% 80$ aseton ile ekstraksiyon yöntemi ile tespit edilen Quercus petraea türüne ait yaprakların klorofil içeriklerinin, SPAD-502Plus ve CCM-300 klorofil metre cihazları ile elde edilen SPAD ve CFR değerleri ile orantılı olduğu görülmüştür. $R^{2}$ değeri en yüksek, uygun görülen denklemler, SPAD ve CFR sonuçlarının, yaprak klorofil içeriklerine dönüştürülmesi için faydalı bulunmuştur.

$\mathrm{Bu}$ çalışmada, yaprak toplam klorofil içeriği birim alan başına $\left(\mathrm{mg} \mathrm{cm}^{-2}\right)$ hesaplanmak üzere, SPAD502Plus cihazının $R^{2}$ değeri $\left(R^{2}=0.9367\right), C C M-300$ cihazının $R^{2}$ değerine $\left(R^{2}=0.8702\right)$ göre daha yüksek bulunmuştur. Bu nedenle, SPAD-502Plus cihazının sapsız meşede yaprak toplam klorofili içeriği belirlemede kullanımının daha uygun olduğu tespit edilmiştir. Ancak, CCM-300 cihazı, SPAD-502Plus cihazının aksine ibreliler, küçük ve düzensiz şekilli yapraklara sahip bitkilerde de ölçüm yapabilmektedir. Bu sebeple CCM-300 bu tarz bitkilerde yaprak klorofil içeriği belirlemede tercih edilmektedir (Repo et al. 2016; Ali ve ark. 2018; Marchetti et al. 2018).

Araştırmacılar her iki cihazın da birbirlerine göre avantaj-dezavantajlarını ve çalışacakları bitki türünü 
de göz önünde bulundurarak, kullanacakları bu optik klorofil metre cihazlarına karar verebilirler.

\section{TEŞEKKÜR}

Bu çalışma, Artvin Çoruh Üniversitesi Bilimsel Araştırma Projeleri Birimi tarafından 2015.F10.02.09 nolu proje ile desteklenmiştir. Mevcut çalışmayı sahip olduğu altyapı ve teknik teçhizat ile destekleyen Artvin Çoruh Üniversitesi Bilim-Teknoloji Uygulama ve Araştırma Merkezi (BiLTEKMER) Müdürlüğü'ne ve personeline de ayrıca teşekkürlerimizi sunarız.

\section{KAYNAKLAR}

Ali S, Khan MA, Kim WC (2018) Pseudomonas veronii KJ mitigates flood stress-associated damage in Sesamum indicum L. Appl Biol Chem 61: 575-585 https://doi.org/10.1007/s13765-018-0392-2

Arnon DI (1949) Copper enzymes in isolated chloroplasts. Polyphenoloxidase in Beta vulgaris. Plant Physiology 24: 1-15

Bielinis E, Jozwiak W, Robakowski P (2015) Modelling of the relationship between the SPAD values and photosynthetic pigments content in Quercus petraea and Prunus serotina leaves. Dendrobiology 73: 125-134

Curran PJ, Dungan JL, Gholz HL (1990) Exploring the relationship between reflectance red edge and chlorophyll content in slash pine. Tree Physiology 7: 33-48

Filella I, Serrano L, Serra J, Peñuelas J (1995) Evaluating wheat nitrogen status with canopy reflectance indices and discriminant analysis. Crop Science 35: 1400-1405

Fujimura S, Shi P, Iwama K, Zhang X, Gopal J, Jitsuyama Y (2009) Comparison of growth and grain yield of spring wheat in Lhasa, the Tibetan Plateau, with those in Sapporo, Japan. Plant Prod Sci 12: $116-123$

Gamon JA, Surfus JS (1999) Assessing leaf pigment content and activity with a reflectometer. New Phytologist 143: 105-117

Gitelson AA, Buschmann C, Lichtenthaler HK (1999) The Chlorophyll Fluorescence Ratio F735/F700 as an Accurate Measure of Chlorophyll Content in Plants. Remote Sens Enviro 69: 296-302
Larcher W (1995) Physiological Plant Ecology, 3rd edn. Berlin, Germany: Springer.

Lichtenthaler HK (1987b) Chlorophyll and carotenoids, the pigments of photosynthetic biomembranes. Methods Enzymol 148: 350382

Marchetti CF, Skrabisova M, Galuszka P, Novak O, Causin HF (2018) Blue light suppression alters cytokinin homeostasis in wheat leaves senescing under shading stress. Plant Physiology and Biochemistry 130: 647-657 https://doi.org/10.1016/j.plaphy.2018.08.005

Markwell J, Osterman JC, Mitchell JL (1995) Calibration of the Minolta SPAD-502 leaf chlorophyll meter. Photosynthesis Research 46: 467-472

Monje OA, Bugbee B (1992) Inherent limitations of nondestructive chlorophyll meters: a comparison of two types of meters. Hortscience 27: 69-71

Moran JA, Mitchell AK, Goodmanson G, Stockburger KA (2000) Differentiation among effects of nitrogen fertilization treatments on conifer seedlings by foliar reflectance: a comparison of methods. Tree Physiology 20: 1113-1120

Peñuelas J, Filella I (1998) Visible and near-infrared reflectance techniques for diagnosing plant physiological status. Trends in Plant Science 3: 151-156

Percival GC, Keary IP, Noviss K (2008) The potential of a chlorophyll content SPAD meter to quantify nutrient stress in foliar tissue of sycamore (Acer pseudoplatanus), english oak (Quercus robur), and european beech (Fagus sylvatica). Arboriculture \& Urban Forestry 34: 89-100

Pinkard EA, Patel V, Mohammed C (2006) Chlorophyll and nitrogen determination for plantation-grown Eucalyptus nitens and $E$. globules using a non-destructive meter. Forest Ecol 223: 211-217

Repo $T$, Launiainen $S$, Lehto $T$, Sutinen $S$, Ruhanen $H$, Heiskanen J, Laurén A, Silvennoinen R, Vapaavuori E, Finér L (2016) The responses of Scots pine seedlings to waterlogging during the growing season. Canadian Journal of Forest Research 46: 14391450 https://doi.org/10.1139/cjfr-2015-0447

Richardson AD, Duigan SP, Berlyn GP (2002) An evaluation of noninvasive methods to estimate foliar chlorophyll content. New Phytologist 153: 185-194

Sardoel AS, Rahbarian P, Shahdadneghad M (2014) Evaluation chlorophyll contents assessment on three indoor ornomental plants with plant growth regulators. European Journal of Experimental Biology 4: 306-310 